ЭКО. - 2018. - № 10

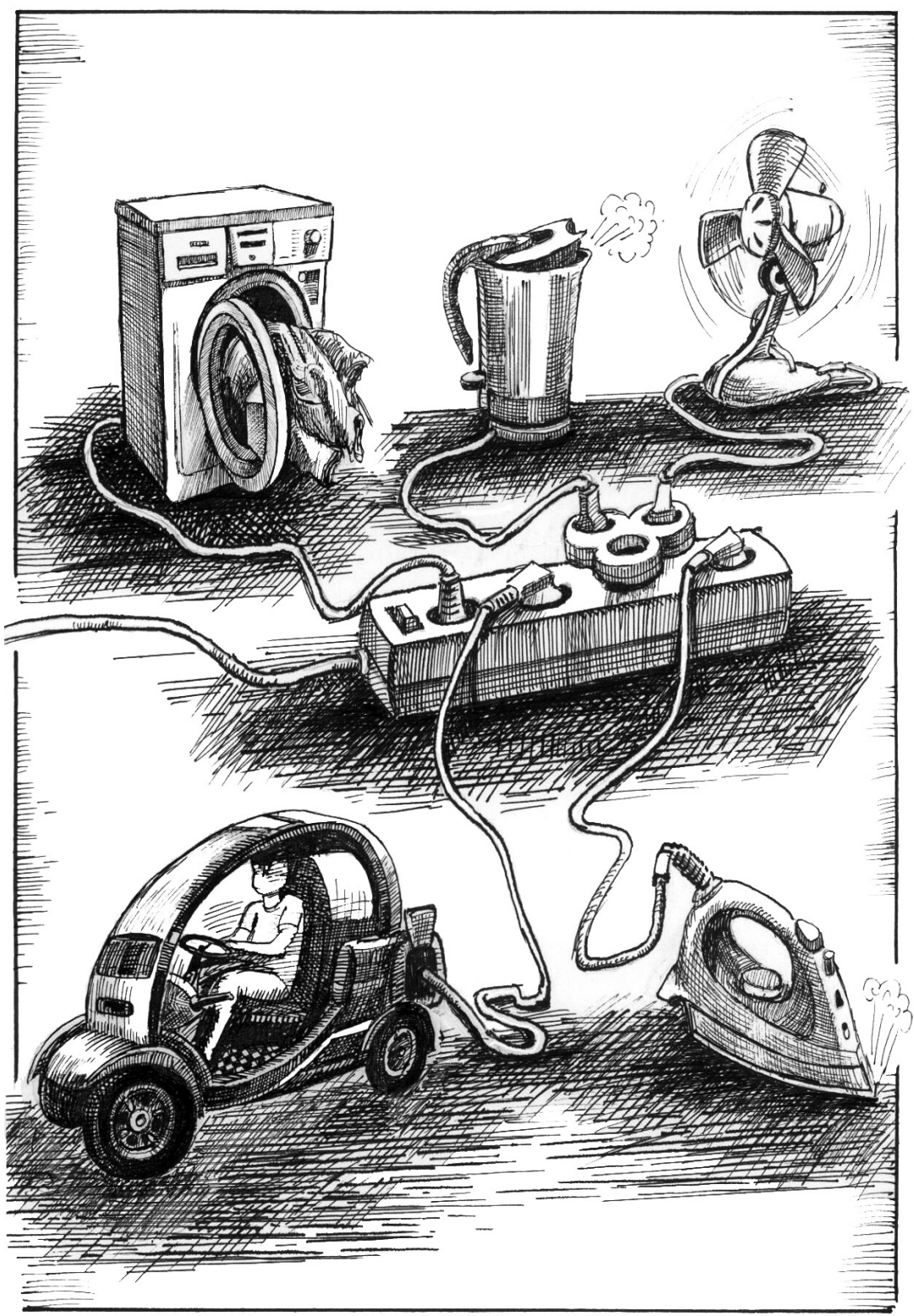




\title{
Газо- или электромобилизация? Россия на обочине прогресса
}

\author{
Х.А. ФАСХИЕВ, доктор технических наук, Уфимский филиал Финансового \\ университета при Правительстве Российской Федерации, Уфимский \\ государственный авиационный технический университет, Уфа. \\ E-mail: faskhiev@mail.ru
}

Выявлены экологические проблемы автотранспорта и показаны пути их решения. Приведены доводы и возражения относительно перевода автотранспорта на газомоторное топливо и на электрическую тягу. Отмечается, что переход на электрическую тягу стратегически более перспективен, чем на газомоторное топливо. Получены данные, показывающие, что электромобили уже сейчас более экономичны, чем автомобили с двигателями внутреннего сгорания. В последнее десятилетие в мире начался «бум» электромобилей. И России следовало бы взять курс на массовое их внедрение, а не вкладывать огромные ресурсы в расширение использования газомоторного топлива. Газ эффективнее применять для генерации электроэнергии и тепла. Освоение массового производства технически более совершенных, дешевых аккумуляторных батарей окончательно отправит двигатели внутреннего сгорания автомобилей на «свалку истории». Широкое использование электротранспорта будет способствовать повышению энергоэффективности, что должно быть принято во внимание при выборе стратегии развития транспорта будущего.

Ключевые слова: автомобиль, экология, газ, моторное топливо, заправочная станция, электромобиль, экономическая эффективность, цена

Россия взяла стратегический курс на газификацию транспорта. На совещании Правительства РФ в апреле 2018 г. Президент России указал на приоритетность по экологическим соображениям автомобилей на газомоторном топливе по сравнению с электромобилями.

Но правилен ли выбранный путь? Каковы доводы «за» и «против» этих альтернатив?

\section{Экологические проблемы автомобильного транспорта}

Развитие традиционного автомобильного транспорта сопровождается усилением негативного воздействия на окружающую среду. При сгорании нефтяного топлива в двигателях внутреннего сгорания образуются около 200 различных вредных веществ. В год автомобиль выбрасывает в атмосферу 800 кг угарного газа, 40 кг оксидов азота и 200 кг различных углеводородов. В целом общее количество вредных веществ, выбрасываемых в 
год автомобилями, превышает 20 млн т и ежегодно увеличивается в среднем на 3\% [Проблемы экологии...].

С учетом того, что автопарк России за последние 10 лет увеличился в 1,5 раза, можно представить, какая экологическая обстановка ожидает нас в ближайшее время, если тенденции в развитии транспорта не изменятся.

Чтобы предотвратить катастрофу, в начале 1990-х годов были приняты национальные и региональные нормы вредных выбросов автомобилей в атмосферу, ужесточавшиеся каждые 3-5 лет. Однако возможности такого подхода практически исчерпаны, поскольку на данном этапе даже для незначительного уменьшения выбросов потребуются огромные вложения.

Экологическая проблема вредных выбросов автотранспорта стратегически может быть кардинально решена за счет перехода на электрическую тягу либо на газомоторное топливо. Какую из этих стратегий выбрать, чтобы не ошибиться?

\section{Газ - альтернатива нефтяному топливу}

В настоящее время около 25 млн автомобилей в мире (1,5\% парка) используют в качестве моторного топлива компримированный (метан) или сжиженный газ (пропан-бутан), и этот показатель ежегодно увеличивается на 30\%. В России газ потребляют 212 тыс. автомобилей (0,5\% парка). По прогнозу Международного газового союза, к 2020 г. парк газового автотранспорта увеличится до 50 млн, а к 2030 г. - до 100 млн транспортных средств (6\% парка).

Доказанные запасы природного газа, используемого как источник моторного топлива, в мире чрезвычайно велики - около 173 трлн м³, плюс еще не открытые запасы, превышающие 120 трлн м³. Газовым топливом является также метан угольных пластов, запасы которого оцениваются в 240 трлн м³. Россия хранитель 40\% запасов природного газа, что делает топливо доступным и дешевым.

Применение природного газа вместо бензина обеспечивает снижение содержания в выхлопных газах окиси углерода с 1,3 до $0,13 \%$, углеводородов - в два раза, а окислов и соединений азота - в пять раз, дымность выхлопа - в три раза [Проблемы экологии...]. Использование газа при незначительных изменениях конструкции автомобиля позволяет из категории «Евро-3» или «Евро-4» вывести его сразу на уровень «Евро-6». 
У газовых двигателей меньше уровень шума, что важно в условиях города, коэффициент полезного действия (КПД) составляет 35-38\% (у бензиновых - 32-35\%). Кроме того, использование природного газа в качестве моторного топлива позволяет увеличить срок смены масла и ресурс двигателя.

Для получения моторного топлива из природного газа не нужна глубокая переработка нефти, необходимая для бензина и дизельного топлива. При одинаковой энергетической ценности $1 \mathrm{M}^{3}$ газа в 2-3 раза дешевле 1 л бензина. Затраты на приобретение и установку газобаллонного оборудования (ГБО) за счет экономии на топливе окупаются в среднем за 50-60 тыс. км пробега, т.е. за 2-3 года. Кроме того, газификация радикально решает вопрос слива топлива без установки дорогостоящей аппаратуры слежения.

Министерство транспорта РФ разработало госпрограмму по расширению использования газа в качестве моторного топлива на транспорте на 2018-2022 гг., объем которой - 769,6 млрд руб., в том числе 163 млрд руб. поступят из бюджета. Половина бюджетных средств будет направлена в автопром, остальное на покрытие льгот по транспортному налогу для владельцев газомоторного транспорта, субсидии на производство техники и льготные парковки. Предполагается также субсидировать лизинг газомоторных автомашин, локомотивов, судов и сельхозтехники. В рамках этой программы предусмотрены обеспечение производства до 30 тыс. газомоторных автомобилей в год, стимулирование производства и эксплуатации транспортных средств на газомоторном топливе и перевод на него до $50 \%$ общественного транспорта и техники для ЖКХ в городах с населением 1 млн жителей; увеличение количества автотранспортных средств, использующих КПГ, в 2,5 раза, сжатый природный газ - до 4 тыс. ед.; уменьшение выбросов загрязняющих веществ от транспортных средств на $30 \%$, снижение затрат на топливо на одно транспортное средство на $12 \%$ и другие меры.

Но правильна ли стратегия перехода на газомоторное топливо? Его использование не решает полностью экологические проблемы. Эксперты Топливного союза отмечают, что выбросы у бензиновых автомобилей, соответствующих требованиям «Евро-5», практически такие же, как у газовых. Газовые автомобили все равно в отдельных случаях будут использовать нефтяное топливо, например, при запуске или отсутствии возможности заправки газом. 
Применение газа в качестве моторного топлива ставит множество серьезных технических проблем. В частности, снижается мощность двигателя, повышается снаряженная масса, газобаллонное оборудование требует дополнительных затрат, возникают проблемы запуска двигателя в холодное время года, есть опасность взрыва газа при утечках. При использовании под газомоторное топливо обычных двигателей снижается их топливная экономичность и ухудшаются скоростно-силовые характеристики. При установке газобаллонного оборудования требуются изменения в конструкции топливной системы, которые не оптимальны для бензина, т.е. автомобиль теряет в мощности и надежности при езде и на бензине. В эксплуатации у газовых автомобилей происходят поломки двигателя, отказы газового оборудования. Тяжелые и находящиеся под высоким давлением горючих газов баллоны увеличивают опасность газовых автомобилей. Автомобили, заправляемые пропан-бутаном, пожаро-, а метановые - взрывоопасны, так как давление КПГ в баллонах превышает 200 атмосфер. Для обеспечения безопасности газовых автомобилей требуются установка современного оборудования 4-го или 5-го поколения и периодическое техническое обслуживание в сертифицированных сервисных центрах.

Если бензиновый автомобиль был на гарантии, то при переводе на газ он ее лишается, даже если имеется сертификат сервисного центра. Кроме того, процедура перевода и получения сертификата на газовый автомобиль довольно сложна и недешева - владельцу придется уплатить 50-60 тыс. руб. У малолитражных автомобилей или при небольших пробегах эти затраты могут и не окупиться. Таким образом, широко рекламируемая экономичность газовых автомобилей не во всем соответствует действительности.

Ключевая проблема перехода на газомоторное топливо - это необходимость создания заправочной и сервисной инфраструктуры. Из-за нехватки заправок автомобили вынуждены совершать холостые пробеги, а сеть газонаполнительных компрессорных станций растет медленно из-за малого числа работающих на метане транспортных средств и низкого спроса на это топливо. Круг замкнулся. По состоянию на июнь 2018 г. на территории России было всего 360 заправок компримированного природного газа (КПГ) (одна заправка - на 21 тыс. км²), тогда как бензиновых - более 29 тыс. Для сравнения: у европейского лидера 
в продвижении газомоторного топлива Италии - 1046 заправок (одна заправка на 300 км²), Германии - 921 (на 400 км²); Шве-

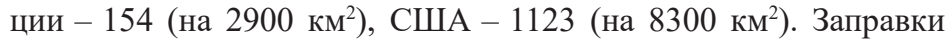
в России распределены по регионам крайне неравномерно: половина сконцентрирована в Центральном, Приволжском и Южном федеральных округах. Не только для частного бизнеса, но и для «Газпрома», главного поставщика метана и строителя заправок КПГ в стране, создание инфраструктуры газомоторного транспорта с неопределенным сроком окупаемости весьма накладно.

Программа газификации автотранспорта в России запоздала на 25-30 лет. Она была актуальна, когда в стране активно формировалась система городских АЗС, которые сейчас трудно и дорого дооснастить газозаправочным оборудованием: инвестиции в него составляют 25-30\% в общей стоимости АЗС. При увеличении числа потребителей газа не исключается быстрый рост его цены.

\section{Есть ли альтернатива газомоторным автомобилям?}

С начала 2000-х годов развитие «зеленого» транспорта во всем мире идет по пути не газовых, а электрических автомобилей. По экологичности электромобилям нет альтернативы.

Возникает вопрос: не лучше ли направить заложенные в газовую программу средства в альтернативный проект - внедрение электромобилей, а газ использовать для генерации электроэнергии и тепла в теплоэлектроцентралях (ТЭЦ)?

Правда, ряд экспертов считают, что переход на электротягу может нанести ещё больший вред экологии, чем автомобили на нефтяном топливе, так как увеличение количества электрокаров приведёт к повышению нагрузки на тепловые электростанции (ТЭС) и росту объёма выбросов вредных веществ в атмосферу, включая сажу, углекислый газ и серные соединения. На тепловых электростанциях сейчас производится около 90\% всей мировой электроэнергии. В российской энергетике на долю ТЭС приходится 68\%, при этом доля «зеленых» генерирующих мощностей такова: гидроэлектростанций - 21\%, атомных $-11 \%$, возобновляемых источников - не более $0,2 \%$.

В качестве топлива в ТЭС в основном используются уголь и газ. Так, в 2015 г. 39\% энергии генерировалось сжиганием угля, $23 \%$ - газа, 4\% - нефти и менее $34 \%$ - за счет экологически чистых 
источников. В таких странах, как Китай, Индия, Польша и ряд других, более 3/4 электроэнергии вырабатывается на угольных ТЭС. В европейской части России большинство ТЭС переведены на газ. Уголь сжигается преимущественно на станциях, расположенных в Сибири и на Дальнем Востоке. Многие тепловые электростанции в России используют несколько видов топлива. Например, на Новочеркасской ГРЭС доля мазута составляет 17\%, газа $-9 \%$, а угля $-74 \%$.

Вредные выбросы ТЭС могут быть существенно сокращены за счет увеличения доли газа в выработке электроэнергии и повышения эффективности сжигания топлива. Так, у современных ТЭС, вырабатывающих только электроэнергию, КПД составляет $39-40 \%$, а у теплоэлектроцентралей достигает $85 \%$. ТЭС, как правило, расположены за пределами населенных пунктов, где и сосредоточены вредные выбросы, в то время как львиная доля выбросов газомоторного транспорта приходится на города.

Страны, где заботятся о своем будущем, сейчас массово внедряют в энергетике «зеленые» технологии. Так, в 2017 г. около $22 \%$ мирового энергопотребления происходило за счет возобновляемых ресурсов. По данным Международного агентства по возобновляемым источникам энергии, благодаря удешевлению «зеленой» энергетики и в связи с ростом цен на нефть, к 2030 г. около 40\% генерируемой электроэнергии будет приходиться на экологически чистую, что в два раза больше сегодняшней доли. Развитие «зеленой» энергетики стало драйвером мировой электрификации транспортных средств. К примеру, в Норвегии - стране, лидирующей по индексу человеческого развития, $98 \%$ электричества производят из возобновляемых источников энергии [Как Норвегия...].

\section{Электромобилизации дан старт}

Переход автомобилей на электрическую тягу позволяет решить ключевую проблему крупных городов - плохую экологию. На Всемирной конференции по климату в Париже было озвучено заявление о том, что Великобритания, Германия и ряд других стран после 2050 г. намерены запретить использование на транспорте нефтяного топлива. Германия приняла резолюцию о запрете производства автомобилей с двигателями внутреннего сгорания с 2030 г. и призывает присоединиться к этой инициативе остальные страны ЕС. Правительство Великобритании объявило, 
что к 2040 г. в стране будут запрещены автомобили с двигателями не только внутреннего сгорания, но и с гибридными. В продаже останутся только электрокары.

Сейчас на рынке предлагаются электромобили «на любой вкус»: гибридные, заряжаемые двигателем внутреннего сгорания (HEV), гибридные с возможностью зарядки от сети (PHEV), чисто электрические (EV), на топливных ячейках (FCV). Лавинообразно растут их производство и продажа (рисунок, табл. 1). В 2017 г. в мире было продано 1,2 млн электромобилей, что на $57 \%$ больше, чем годом ранее, причем 66\% из них - чисто электрические. В целом на электрокары пока приходится 1,3\% всех мировых автомобильных продаж. Однако в некоторых странах их доля уже довольно существенна: в Норвегии - 39,2\% всех продаж, Исландии $-14 \%$, Швеции $-5,3 \%$. По прогнозам экспертов, в 2018 г. объем продаж электромобилей увеличится на $60 \%$. При этом доля чисто аккумуляторных автомобилей составит 70\% [Фасхиев, 2018а].

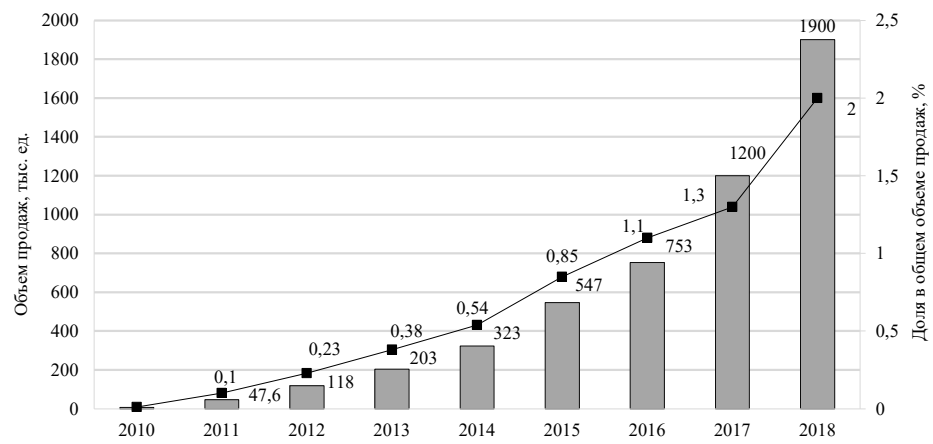

Источник: [Общее количество электромобилей...].

Динамика продаж электромобилей и гибридов в мире в 2010-2018 гг.

Эта тенденция продолжится, так как в мире из года в год увеличиваются инвестиции в «зеленый» транспорт. В 2016 г. они составили 2 млрд долл., что в два раза больше, чем годом ранее, и на 650 млн долл. больше, чем за три предыдущих года, вместе взятые. Речь идет только о тех инвестициях в стартапы, которые связаны непосредственно с электромобилями (их выпуск, производство зарядных станций), а есть еще вложения автопроизводителей и программы господдержки. Только один концерн 
Daimler планирует потратить 10 млрд евро на создание 10 моделей электромобилей к 2025 г., Volkswagen - разработать 30 новых моделей электромобилей и довести их продажи до 1 млн в год.

\section{Таблица 1. Объем продаж электромобилей по странам в 2005-2016 гг., тыс. ед.}

\begin{tabular}{|l|c|c|c|c|c|c|c|}
\hline \multicolumn{1}{|c|}{ Страна } & $\mathbf{2 0 0 5}$ & $\mathbf{2 0 1 0}$ & $\mathbf{2 0 1 2}$ & $\mathbf{2 0 1 3}$ & $\mathbf{2 0 1 4}$ & $\mathbf{2 0 1 5}$ & $\mathbf{2 0 1 6}$ \\
\hline Канада & - & - & 2,02 & 3,12 & 5,07 & 6,96 & 11,58 \\
\hline Китай & - & 1,43 & 9,90 & 15,34 & 73,17 & 207,38 & 336 \\
\hline Франция & 0,01 & 0,19 & 6,26 & 9,62 & 12,64 & 22,95 & 29,51 \\
\hline Германия & 0,02 & 0,14 & 3,37 & 6,93 & 12,74 & 23,19 & 24,61 \\
\hline Индия & - & 0,35 & 1,43 & 0,19 & 0,41 & 1,00 & 0,45 \\
\hline Япония & - & 2,44 & 24,44 & 28,88 & 32,29 & 24,65 & 24,85 \\
\hline Ю. Корея & - & 0,06 & 0,51 & 0,60 & 1,31 & 3,19 & 5,26 \\
\hline Нидерланды & - & 0,12 & 5,12 & 22,42 & 15,09 & 43,77 & 24,48 \\
\hline Норвегия & - & 0,39 & 4,51 & 8,52 & 19,76 & 35,61 & 50,18 \\
\hline Швеция & - & - & 0,93 & 1,55 & 4,67 & 8,59 & 13,42 \\
\hline Великобритания & 0,22 & 0,28 & 2,69 & 3,75 & 14,74 & 29,34 & 37,91 \\
\hline США & 1,12 & 1,19 & 53,24 & 96,70 & 118,78 & 113,87 & 159,62 \\
\hline Россия & - & н. д. & н. д. & 0,096 & 0,082 & 0,116 & 0,083 \\
\hline Другие & 0,53 & 0,18 & 3,64 & 6,05 & 12,77 & 26,62 & 35,31 \\
\hline Итого & 1,89 & 6,78 & 118,06 & 203,66 & 323,42 & 547,12 & 753,17 \\
\hline
\end{tabular}

Источник: данные Международного энергетического агентства. URL: https:// itc.ua/blogs/obshhee-kolichestvo.

Парк электромобилей к 2017 г. достиг 4,1 млн ед. (0,2\% общего парка) [Общее количество...]. В настоящее время в мире выпускается более 130 моделей легковых электромобилей, действует более 10 тыс. «быстрых» зарядных станций. Практически все автомобильные заводы в своей линейке имеют электромобили и очень интенсивно наращивают объемы их выпуска. Так, General Motors к 2023 г. планирует освоить производство как минимум 20 моделей полностью электрифицированных автомобилей. C 2019 г. все легковые автомобили компании Volvo Cars будут оснащаться только электродвигателем. Британская Land Rover в 2017 г. сообщила, что с 2020 г. планирует выпускать все новые модели только на базе электрических или гибридных двигателей. Такие планы имеются и у других автопроизводителей.

Самой продаваемой среди моделей электромобилем и гибридов в мире в 2016 г. была Tesla Model S (52,6 тыс.ед.) (рост к 2015 г. на 4,4\%) (табл. 2). На долю пяти крупнейших производителей 
электромобилей приходится более $50 \%$ мирового рынка. Пятерку лидеров возглавляет китайский концерн BYD с долей 13,6\%. Следом идут Renault-Nissan (11,3\%), Tesla Motors (10,8\%), Volkswagen $(7,8 \%)$ и BMW (7,7\%), в линейке у которых (кроме Tesla) более пяти моделей. Основные продажи (95\%) приходятся на десять стран - Китай, США, Японию, Канаду, Норвегию, Великобританию, Францию, Германию, Нидерланды и Швецию, где принят ряд преференций, льгот и преимуществ как для производителей, так и покупателей «зеленой» техники [Сколько сейчас эксплуатируется...].

Таблица 2. 10 самых продаваемых моделей электромобилей и гибридов в 2015-2016 гг.

\begin{tabular}{|c|l|c|c|c|}
\hline Место & Модель (страна) & $\mathbf{2 0 1 5}$ г. & $\mathbf{2 0 1 6}$ г. & В \% к 2015 г. \\
\hline 1-е & Tesla Model S (США) & 50366 & 52600 & $+4,4$ \\
\hline 2-e & Nissan Leaf (Япония) & 43870 & 49818 & +7 \\
\hline 3-е & BYD Tang (Китай) & 18375 & 31405 & +71 \\
\hline 4-e & Chevrolet Volt (США) & 17508 & 28295 & +67 \\
\hline 5-e & Mitsubishi Outlander PHEV (Япония) & 43259 & 27850 & -36 \\
\hline 6-e & BMW i3 (Германия) & 24083 & 25576 & +6 \\
\hline 7-e & Tesla Model SX (США) & 214 & 25372 & +11756 \\
\hline 8-е & BYD Qin (Китай) & 31898 & 21868 & -31 \\
\hline 9-е & Renault Zое (Франция) & 18846 & 21626 & +16 \\
\hline 10-е & ВYD e6 EV (Китай) & 7034 & 20609 & +193 \\
\hline & Другие & 292757 & 470209 & $+60,6$ \\
\hline & Итого & 548210 & 773563 & $+41,1$ \\
\hline
\end{tabular}

Источник: составлено на основе данных [Tesla Model...].

Мировой парк электромобилей, увеличившийся с 2005 г. по 2014 г. с 1,4 тыс. до 715,2 тыс. ед., сделал рывок: в 2017 г. 4,1 млн, в 2018 г. - 6,0 млн ед. [Общее количество электромобилей...]. По прогнозам Международного энергетического агентства, в 2020 г. мировой парк электромобилей составит 20 млн ед., а в 2040 г. - 266 млн. По прогнозам ОПЕК, к 2040 г. на электромобили придется $51 \%$ всех продаж, что приведет к радикальным изменениям на нефтяных рынках.

\section{Двигатель прогресса - льготы и субсидии}

Электромобили сейчас дороже бензиновых в 2-3 раза, что, естественно, отпугивает потенциальных покупателей. По этой причине многие страны стимулируют как покупателей, так и производителей электромобилей, вводя на законодательном уровне 
разнообразные льготы и преференции (табл. 3). Налоговые стимулы при покупке ввели 15 из 27 государств - членов ЕС. Самой продвинутой в этом отношении считается Норвегия, где литр бензина стоит 1,7 евро, что в среднем втрое выше, чем, например, в США или в России. Норвегия намерена с 2025 г. разрешить продажу автомобилей только с нулевым уровнем выбросов. В 2017 г. доля электрокаров в объеме продаж легковых машин в этой нефтедобывающей стране достигла рекордных 52\% (в 2014 г. - 12\%). Парк электромобилей в стране уже насчитывает 150 тыс. ед. (5\% парка). В стране огромная сеть бесплатных зарядных станций около 10 тыс. пунктов. На миллион жителей Норвегии приходится 7,3 электрозаправки, тогда как в США, например, 2,1, в Дании 1,9. Кроме того, у 96\% владельцев электрокаров дома есть персональные зарядные станции. По подсчетам экспертов Gronn Bil, используя электромобиль, житель Осло экономит в год в среднем 3336 евро. Общий объем государственных субсидий в поддержку электромобилей оценивается в 5 млрд долл.

\section{Таблица 3. Льготы и дотации покупателям электромобилей}

\begin{tabular}{|c|c|}
\hline Норвегия & $\begin{array}{l}\text { Импортная пошлина - 0\%. Отменены налог на покупку, ежегодный регистрационный сбор, } \\
\text { налог для корпоративных авто, плата за дорогу; ставка НДС равна нулю. Бесплатные зарядка, } \\
\text { парковка, проезд на паромах. Разрешено движение по выделенным полосам общественного } \\
\text { транспорта }\end{array}$ \\
\hline $\begin{array}{l}\text { Велико- } \\
\text { британия }\end{array}$ & $\begin{array}{l}\text { Годовые налоги уменьшают на сумму до 25\% стоимости машины (но не более } 7800 \text { долл.), } \\
\text { при покупке коммерческого электромобиля-налоговая льгота до 20\% (не более } 12500 \text { долл.). } \\
\text { В Лондоне есть бесплатные парковки в определенных местах, а также 4-часовая зарядка } \\
\text { автомобиля }\end{array}$ \\
\hline $\begin{array}{l}\text { Португа- } \\
\text { лия }\end{array}$ & Субсидия в размере 5000 евро, освобождение от регистрационного сбора \\
\hline Дания & Льготы по налогу на доходы, нет сбора при регистрации, бесплатная парковка в Копенгагене \\
\hline США & $\begin{array}{l}\text { Дотация в размере } 25 \% \text { стоимости машины (не более } 7500 \text { долл.), налоговые льготы на сумму } \\
\text { в размере } 50 \% \text { от цены «зарядки» (до } 2 \text { тыс. долл.) }\end{array}$ \\
\hline Япония & $\begin{array}{l}\text { Отменены единовременный налог на покупку и ежегодный транспортный сбор, что снижает } \\
\text { стоимость автомобиля в среднем на } 45 \%\end{array}$ \\
\hline $\begin{array}{l}\text { Нидер- } \\
\text { ланды }\end{array}$ & $\begin{array}{l}\text { Освобождение от уплаты налогапри регистрации и сбора запользование дорогами. Отдельные } \\
\text { места в паркингах с зарядкой }\end{array}$ \\
\hline Германия & Субсидии в 4 тыс. евро при покупке электромобиля и 3 тыс. - при покупке гибрида \\
\hline Франция & Эко-бонусы покупателям транспорта с низкими выбросами - до 6300 евро \\
\hline Украина & Освобождаются от НДС и акциза в размере 109 евро на импорт электрокара до 1 января 2020 г. \\
\hline Эстония & $\begin{array}{l}\text { Дотация в размере } 50 \% \text { стоимости автомобиля (не более } 18 \text { тыс. евро), } 1 \text { тыс. евро для } \\
\text { приобретения и монтажа зарядного устройства }\end{array}$ \\
\hline Россия & $\begin{array}{l}\text { Субсидии производителям электротранспорта (КамАЗ и ГАЗ) - по } 900 \text { млн руб. ежегодно } \\
\text { до } 2025 \text { г. Бесплатная парковка в Москве и Санкт-Петербурге, в Московской области отменен } \\
\text { транспортный налог }\end{array}$ \\
\hline
\end{tabular}


Пример Норвегии показывает, что при активном государственном стимулировании электромобилизация страны - вполне осуществимая, причем в кратчайшие сроки, задача.

Китай, в котором работают шесть из 10 крупнейших мировых компаний, освоивших массовое производство электромобилей, поставил цель к 2025 г. достичь 20\%-й доли их продаж. Благодаря государственным субсидиям Китай в 2015 г. по объему продаж электромобилей вышел в мировые лидеры. В 2017 г. каждый второй электромобиль (652 тыс.) продавался в Китае, где сейчас сосредоточена 1/3 мирового парка транспорта на электрической тяге. Более $40 \%$ выпускаемых в мире электромобилей производится в Китае, причем из списка «топ-30» моделей на китайские бренды приходится 45\% выпуска. Пекин поставил грандиозную задачу: к 2025 г. продавать не менее 7 млн новых электромобилей в год, а к 2040 г. вообще запретить продажи бензиновых и дизельных машин.

В крупных китайских городах из-за крайне загрязненного воздуха ограничена регистрация автомобилей с двигателями внутреннего сгорания, поэтому для многих покупателей электромобили становятся альтернативой, тем более что государство предоставляет им финансовые льготы.

Одна из мер стимулирования покупок электромобилей - это возможность зарегистрировать их быстро и бесплатно, экономя на этом сумму, эквивалентную от 300 тыс. до 1 млн руб. В Китае введена система государственных и провинциальных субсидий покупателям «зеленых» автомобилей в размере до 50 тыс. юаней (7700 долл.). Покупатель электромобиля получает компенсацию в размере около $35 \%$ его розничной стоимости. В Пекине все новые такси должны быть электрическими. В городе установлены 100 тыс. пунктов зарядки аккумуляторов. Государство стимулирует муниципалитеты за счет субсидирования строительства зарядных станций и регулирования цен на электроэнергию. Госсовет Китая поставил задачу построить как минимум одну зарядную станцию на каждые 2 тыс. электромобилей, а к 2020 г. - расширить зарядную инфраструктуру для обеспечения потребностей около 5 млн электрокаров. Количество зарядных станций в Китае уже превысило 500 тыс. Буквально за 3-5 лет Китаю удалось запустить процесс электрификации транспорта, охватив все его аспекты: производство электромобилей и компонентов для них, создание сети зарядных станций, сервис и утилизацию аккумуляторов. 


\section{Россия вне мирового тренда}

Россия, с ее нефтяными запасами, сравнительно низкими ценами на нефтяное моторное топливо, лояльными экологическими требованиями и, самое главное, всемогущими нефтегазовыми лоббистами, находится вне мирового тренда электромобилизации. В нашей стране пока нет условий для развития электротранспорта. В начале 2018 г. был разработан проект плана по стимулированию производства и использования электротранспорта на период 2018-2020 гг., предусматривающий освобождение владельцев электромобилей от транспортного налога, предоставление бесплатной парковки с зарядными устройствами. В плане также предусмотрено снижение ввозных таможенных пошлин на импортные комплектующие для сборки электромобилей совместно с иностранными компаниями. В 2017 г. Минэкономразвития предложило выделять субсидии производителям электротранспорта, в частности КАМАЗу и ГАЗу, - по 900 млн руб. ежегодно до 2025 г.

У Правительства РФ имеются наработки по предоставлению налоговых льгот инвесторам электрозаправок, выделению квот бюджетным организациям на покупку электротранспорта, упрощению порядка установки устройства «Эра-Глонасс» на электромобили. Перспективы развития электромобильного транспорта в России будут зависеть от того, насколько их приобретение и эксплуатация будут выгодны для покупателей, а также от развития инфраструктуры. А пока этот рынок в России находится в зачаточном состоянии - на 01.01.2018 г. парк составил 1,8 тыс. автомобилей семи моделей. За 2017 г. было продано всего 95 электрокар, что на $28 \%$ больше, чем годом ранее. Объем продаж электромобилей в РФ не превышает $0,01 \%$ общемирового уровня [В России...].

Российскому покупателю за импортный электрокар, кроме его цены, приходится платить таможенную пошлину (30\% от цены), акциз по ставке 15 руб./л.с. (при мощности двигателя 90-150 л.с., 153 руб./л.с. - при мощности от 150 л.с.), таможенный сбор $(0,15 \%)$, НДС (18\%) и утилизационный сбор (17,2 тыс. руб.). Импортный электромобиль на российском рынке стоит как минимум в 1,5 раза дороже, чем в стране-производителе. Временная отмена таможенных пошлин на ввоз электромобилей в 2017 г. никак не повлияла на рынок. Так что электромобиль в России покупают обычно богатые в качестве второго или даже третьего и, как правило, заряжают в индивидуальных станциях 
дома (заметим, что в США 85\% владельцев электромобилей тоже пользуются только домашними зарядными станциями и платят за электроэнергию по ночному льготному тарифу).

Доступность электромобилей для россиян можно обеспечить, освоив собственное производство. Пока у производителей нет стимула для их выпуска, так как в стране отсутствуют понятные для конечного потребителя выгоды приобретения. Российские инновационные проекты - электрокары Marussia и «ё-мобиль», которым предрекали большое будущее, на фоне экономической нестабильности в стране развалились. Освоенная в 2012 г. ВАЗом электрическая BA3-1817 Ellada на базе «Калины» была продана в количестве всего 93 ед. Автомобиль имел пробег менее 100 км на одной зарядке, при этом его цена - около 1 млн руб., т.е. дороже бензиновых иномарок своего класса. Естественно, он не пользовался спросом, и проект был закрыт.

C учетом этого опыта завод разработал другую модель - Lada Vesta EV с литий-ионным аккумулятором и мощностью двигателя в 60 кВт. Электрокар способен в летнее время преодолеть до 150 км без подзарядки. На полную зарядку требуется девять часов, а при наличии доступа к трехфазной сети - не более трех часов. Самое «больное» место Vesta EV - цена. По приблизительным подсчетам, она достигает 3 млн руб. (при цене бензиновой «Весты» в полной комплектации 800 тыс. руб.). Вряд ли автолюбители согласятся отдать такие деньги за автомобиль с достаточно низкими характеристиками скорости и динамичности, когда за такую же сумму можно приобрести мощную спортивную иномарку с бензиновым двигателем.

Продаваемые ныне электромобили не рассчитаны на российские просторы - запас хода, за редким исключением, не превышает 150-200 км. В стране нет ни одного специализированного сервисного центра. Правда, конструкция электрокаров намного проще, чем бензиновых машин. У них нет бензинового двигателя, сцепления, коробки передач, шарниров угловых скоростей, не нужно менять масло, фильтры, их можно ремонтировать в обычном автосервисе. По данным агентства «АВТОСТАТ», на этом рынке более 39 тыс. операторов, большинство из которых вполне смогут обслуживать электрические автомобили.

Не решена и проблема создания сети зарядных станций. В России, по оценкам экспертов, в начале 2018 г. было около 
200 станций быстрой зарядки, из них около 100 - в Москве, 15 - в Санкт-Петербурге. К концу 2018 г. администрация Москвы планирует довести их число до 200. В 2015 г. Правительство РФ приняло постановление, по которому все российские АЗС (их более 30 тыс.) до 1 ноября 2016 г. должны были установить зарядные устройства. Однако из-за отсутствия спроса заправки пока не спешат инвестировать в зарядную инфраструктуру. Когда цена электромобилей приблизится за счет господдержки к цене бензиновых аналогов, тогда и производители проявят активность на этом сегменте рынка, а инвесторы начнут вкладываться в развитие инфраструктуры зарядных станций.

Опыт стран ЕС показывает, что реальное отношение числа электромобилей к числу зарядных станций должно составлять 5:1 (в США -10:1, в Норвегии - 15:1). Чем больше станций зарядки в населенном пункте, тем популярнее электромобили. Зарядные станции можно создать довольно быстро. Например, в Японии буквально в течение пяти лет было оборудовано 40 тыс. зарядных станций (число бензиновых автозаправочных станций - 35 тыс.) [В Японии...]. Большое внимание в Японии уделяется развитию скоростных зарядных пунктов, и сейчас страна является лидером по их числу (6469 ед.). Второе место принадлежит странам ЕС - 3028 станций, третье место - у США - 1686 при общем числе около 9000.

Еще одним препятствием для развития рынка электромобилей в России является холодный климат. При отрицательных температурах литий-ионные аккумуляторы могут терять до $30-40 \%$ емкости. Система подогрева аккумуляторов будет потреблять часть энергии, что сокращает дальность поездок. Кроме того, в зимний период на обогрев салона и освещение будет расходоваться до 20-30\% емкости аккумуляторов. В итоге и так «скромный» запас хода может уменьшиться до 80-100 км. Получается, автомобиль дорогой, заряжать его негде, запас хода мизерный отсюда и единичные продажи электромобилей в России.

\section{Есть ли экономическая выгода от электромобиля?}

Мнение, что электромобили всегда будут дороже, чем машины с ДВС, скорее, миф, чем реальность. Расчеты экспертов бизнес-школы «Сколково» показывают, что стоимость за три 
года владения Tesla Model S уже в 2013 г. стала ниже, чем у бензинового Mercedes $\mathrm{S}-120$ и 110 тыс. долл. соответственно [Четыре мифа...].

Сравнение топливной экономичности двух хэтчбеков Nissan распространенного в России электромобиля Leaf (мощность 84 кВт, цена - 23 тыс. евро) и Tiida с бензиновым двигателем (90 кВт, 18 тыс. евро) показало, что 1 км пробега для Tiida обойдется в 4,2 раза дороже. Разница в цене в 5 тыс. евро при курсе 72 руб./евро за счет экономии топлива может быть «скомпенсирована» только при пробеге 165 тыс. км, т.е. при годовом пробеге 30 тыс. км для этого потребуется около пяти лет [Как Норвегия...].

Если же Tiida перевести на метан, то затраты на топливо у нее будут на 65\% больше. Можно сделать вывод о том, что электромобиль по затратам на топливо однозначно экономичнее, чем газомоторные и бензиновые.

Расчеты автора показывают, что применение электротяги дает особую выгоду на коммерческом транспорте, где расход топлива и пробеги несравненно выше, чем у легковых автомобилей. Сравнительные расчеты экономической эффективности электротягача Tesla Semi c полуприцепом и аналогичного импортного дизельного тягача DAF XF105 показали, что совокупная стоимость владения электрогрузовиком на 5377 тыс. руб. меньше, чем дизельным. При этом суммарные текущие расходы за 10 лет эксплуатации дизельного тягача составили 44387 тыс. руб., а у Tesla Semi - на 13799 тыс. руб. меньше. Удельные эксплуатационные затраты электрического тягача на 1 км пробега ниже на $45 \%$ за счет того, что он на 1 км пробега расходует в два раза меньше электроэнергии, чем дизельный автопоезд. Затраты на топливо у дизельного тягача за 10 лет на 9600 тыс. руб. больше, чем у Tesla Semi на электроэнергию. Кроме того, затраты на техническое обслуживание, текущий и капитальный ремонт электрогрузовика за 10 лет на 3569 тыс. руб. меньше, чем у конкурента [Фасхиев, 2018б].

На улицах городов России начали появляться регулярные «зеленые» маршруты. Так, в Подмосковье в Одинцовском филиале «Мострансавто» с 2017 г. эксплуатируется разработанный в ПАО «КАМАЗ» электробус КАМАЗ-6282. Литий-титанатные аккумуляторы с энергоемкостью 70,4 кВт.ч обеспечивают автобусу пробег на одной зарядке в 38 км. Электробус в день выполняет два рейса - утренний и вечерний - на маршруте протяженностью 30 км. Остальное время отводится на зарядку батарей, для чего машина возвращается в парк. Из-за отсутствия емкого, легкого и дешевого аккумулятора автобус не может полноценно эксплуатироваться, следовательно, имеет скромные коммерческие результаты. Хотя для него реже требуется сервисное обслуживание, не нужен ряд расходных материалов (моторные и трансмиссионные масла, фильтры). Затраты на электроэнергию у КАМАЗ-6282 в пять раз меньше, чем на дизельное топливо, при том же объеме перевозок. В «Мострансавто» посчитали, что расходы на их обслуживание не превысят 0,5 руб./км, тогда как дизельный автобус только на топливо требует 8 руб./км, т.е. в 16 раз больше. Правда, электробус стоит недешево - 25 млн руб., что втрое дороже аналогичного с дизельным двигателем. При такой цене сэкономленные электробусом на топливе средства даже при ресурсе до списания 
в 1 млн км явно недостаточны, чтобы компенсировать переплату при покупке. Высокая цена электромобилей обусловлена дороговизной применяемых в них аккумуляторов, которые в России не производятся.

Как предрекают эксперты, если нормы на выбросы вредных веществ продолжат ужесточаться, к 2020 г. автомобили с бензиновыми и дизельными двигателями по цене догонят электромобили. В то же время за счет падения цен на самый дорогой компонент электромобиля - аккумуляторы - будет снижаться цена и электромобиля.

\section{Батарейная поддержка}

Ключевые проблемы современного электротранспорта - высокая цена, привязанность к зарядной инфраструктуре, большой вес - вызваны несовершенством применяемых аккумуляторов, цена которых пока составляет около 40\% стоимости автомобиля.

Развитие электромобилей, пригодных для реальной эксплуатации, началось после изобретения в 1986 г. Дж. Гудэнафом кобальтата лития. На его основе через пять лет фирма Sony создала литий-ионные аккумуляторы. В отличие от кислотно-свинцовых они имеют высокую энергоемкость, возможность быстрой зарядки, большое число циклов зарядки/ разрядки, широкий диапазон рабочих температур, не требуют обслуживания. Сфера применения литий-ионных источников огромна. Производство батарей - это перспективнейшая новая отрасль, которая в ближайшем будущем может изменить мир. Ныне выпускаемые литий-ионные батареи как по коммерческим, так и по техническим характеристикам далеки от совершенства, к тому же они небезопасны.

Исследователи по всему миру ведут интенсивные поиски по усовершенствованию конструкции, снижению цены батарей. Есть и значимые результаты. Так, компания Tesla создала батарею емкостью 1000 кВт.ч, которая позволяет 37-тонному автопоезду осуществлять пробег на одной зарядке до 800 км. С развитием технологий снижается и цена батарей. В 2010 г. удельная стоимость батарей равнялась 750 долл./кВт·ч, а 2018 г. она снизилась до 190 долл./кВт·ч, а у Tesla - до 120 долл./кВт·ч.

В стоимостном выражении в 2010 г. объем мирового рынка литий-ионных аккумуляторов составлял 9,1 млрд долл., а к 2016 г. он вырос до 26 млрд долл. Доля России на этом рынке - менее 0,3\%. По прогнозу агентства Headwork Analytics, к 2026 г. рынок литий-ионных аккумуляторов в мире вырастет более чем вдвое и достигнет 50 млрд долл. [Потребление...].

Лидер в сфере электромобилей - Tesla - в 2020 г. планирует запустить второй из пяти планируемых заводов-гигантов Gigafactory, который будет производить аккумуляторы на 35 ГВт·ч в год. Пока ни один завод не может производить литий-ионные аккумуляторы для электрокаров в тех объемах, которые нужны компании Tesla, планирующей на 2018 г. выпустить 500 тыс. электромобилей. 
Китай на территории США строит заводы, способные производить батареи суммарно на 120,9 ГВт·ч в год. Этого хватит для оснащения до 1,5 млн автомобилей Tesla Model S. B Китае разработана программа усиления своего доминирующего положения на рынке батарей. По данным Bloomberg, 55\% литий-ионных батарей сейчас производится в Китае, $10 \%$ - в США. По прогнозам, к 2020 г. мировые мощности производства литий-ионных батарей достигнут 273 ГВт.ч в год. Китай планирует довести свою долю на этом рынке к 2020 г. до 65\%. Следствием роста объемов выпуска батарей будет падение их себестоимости, что даст толчок дальнейшему расширению рынка электромобилей.

Производства литий-ионных аккумуляторов для бытовой электроники гражданского назначения в России пока нет. Единственным предприятием, способным серийно выпускать современные литий-ионные аккумуляторы высокой ёмкости для электротранспорта и систем накопления энергии, является завод «Лиотех» (Новосибирск), а ОАО «Аккумуляторная компания "Ригель”», Верхнеуфалейский завод «Уралэлемент», ПАО «Сатурн», АО «НПК «Альтернативные технологии», ОАО «Энергия» производят лишь малые партии для нужд гособоронзаказа. В 2016 г. Россия импортировала литий-ионных аккумуляторов на сумму 71,5 млн долл., что в 2,5 раза больше, чем в 2010 г., из них 62\% поставок приходилось на Китай. Доля ООО «Лиотех» составила всего 2,5\% [Потребление литий-ионных батарей...].

Электротранспорту нужны крупногабаритные, энергоемкие аккумуляторы, материалы для них должны быть дешевыми. В лабораториях по всему миру развернуты масштабные исследования по усовершенствованию батарей, удешевлению их производства. Учеными Калифорнийского университета Боулдер создан твердотельный аккумулятор, который легче, безопаснее и дешевле, чем литий-ионный, его емкость в три раза выше. Он не боится ударов и может хранить в несколько раз больший заряд. Электролиты на основе керамики сохраняют высокую проводимость при минус $20^{\circ} \mathrm{C}$, поэтому новая батарея будет работоспособна и при низких температурах.

В Кембриджском университете разработан литий-кислородный аккумулятор, который обладает чрезвычайно высокой плотностью энергии, эффективнее на 90\% существующих аналогов и может выдержать более двух тысяч циклов подзарядки. 
Разработчикам компании Power Japan Plus за счет использования дешевых компонентов удалось увеличить скорость зарядки батарей в 20 раз.

Есть и другие интересные разработки в этой сфере. Ведутся исследования по замене дорогого лития в батареях натрием. Принцип работы натриевых аккумуляторов аналогичен литиевым - для переноса заряда в них используются ионы металла. Основной недостаток натриевой технологии - медленная зарядка и низкие токи. Ученым компании BroadBit удалось решить эти проблемы - их батареи заряжаются за пять минут и имеют большую емкость. Одним словом, если аккумуляторы будут прогрессировать такими темпами, амбициозные прогнозы экспертов по замене двигателей внутреннего сгорания электрическими могут сбыться гораздо раньше, чем предполагалось.

Итак, будущее за электротранспортом, энергия для которого будет получена из возобновляемых источников. Применение газа в роли моторного топлива в корне не решает экологическую проблему на транспорте и является лишь промежуточным этапом в эволюции транспортных средств. Газовые автомобили не обеспечивают «нулевые выбросы», КПД их двигателей конструктивно достиг своего предела, и ждать от них энергоэффективного «зеленого» будущего не приходится.

Прогресс в сфере выработки электроэнергии за счет возобновляемых источников и накопителей энергии однозначно определил курс развития транспорта - в будущем он должен быть на электрической тяге. Нецелесообразно дополнительно к имеющейся жидкотопливной заправочно-сервисной инфраструктуре в стране создавать еще одну весьма затратную - газомоторную. Курс на газофикацию транспорта стратегически бесперспективен, так как страна не получает нового качества развития и остается потребителем готовых решений вчерашнего дня. Газ целесообразнее сжигать в локально сосредоточенных высокоэффективных теплоэлектроцентралях, чем в двигателях миллионов автомобилей с КПД менее $35 \%$.

Стратегический курс на газ на транспорте может оставить Россию на обочине промышленно-технической революции первой половины XXI века-электромобилизации. Имеющиеся 
ресурсы должны быть направлены на организацию производства электромобилей, их компонентов, развитие инфраструктуры, генерацию энергии за счет возобновляемых источников. Не имея научно-производственного задела в такой высокотехнологичной, наукоемкой отрасли, как производство аккумуляторных батарей, России вряд ли удастся встать в один ряд в электромобилизации со странами, ориентированными на будущее.

\section{Литература}

В России в 2017 году купили всего 95 новых электромобилей, и 62 из них Tesla [Эл. pecypc]. URL: https://auto.newsru.com/article/19jan2018/Tesla (дата обращения: 03.06.2018).

В Японии число зарядных станций для электромобилей уже больше, чем традиционных [Эл. ресурс]. URL: https://avtomaniya.com/site/publicationfull/12500 (дата обращения: 18.06.2018).

Как Норвегия отказывается от бензина [Эл. ресурc]. URL: https://www. the-village.ru/village/city/abroad/279706-elektrokary-v-norvegii (дата обращения: 18.06.2018 г.).

Общее количество электромобилей в мире [Эл. pecypc]. URL: https://itc. ua/blogs/obshhee-kolichestvo-elektromobiley-v-mire-prevyisilo-otmetku-2-mlnekzemplyarov-iz-kotoryih-1-2-mln-chistyih-elektromobiley-i-0-8-mln-podklyuchaemyih-gibridov (дата обращения: 25.01.2018).

Потребление литий-ионных батарей в России [Эл. pecypc]. URL: http:// alexmasanov.ru/blog/litium-ion-batteryin-russia (дата обращения: 28.02.2018).

Проблемы экологии и загрязнение атмосферного воздуха выхлопами газа автомобильного транспорта [Эл. ресурс]. URL: https://vuzlit.ru/1340135/ problemy_ekologii_zagryaznenie_atmosfernogo_vozduha_vyhlopami_gaza_ avtomobilnogo_transporta (дата обращения: 14.06.2018).

Сколько сейчас эксплуатируется электромобилей в мире [Эл. ресурс]. URL: http://beelead.com/skolko-elektromobilej-mire (дата обращения: 16.06.2018).

Фасхиев $X$. А. Электрогрузовик с автопилотом - будущее магистральных перевозок // Логистика сегодня. 2018а. № 1. С. 42-56.

Фасхиев $X$. А. Экономическая эффективность грузового автомобиля на электрической тяге // Автомобильная промышленность. 2018б. № 6. С. 3-7.

Четыре мифа об электромобилях и веке бензина [Эл. ресурc]. URL https:// republic.ru/biz/1106503 (дата обращения: 28.02.2018).

Tesla Model S и Nissan Leaf - самые продаваемые электромобили в мире в 2016 году [Эл. ресурс]. URL: https://cleantechnica.com/2017/02/04/tesla-models-clocked-as-worlds-best-selling-electric-car-in-2016 (дата обращения: 03.06.2018).

Статья поступила 18.06.2018.

\section{Summary}

Faskhiev Kh. A., Ufa Branch of the Finance University under the Government of the Russian Federation, Ufa State AviationTechnical University, Ufa 


\section{Gas or Electric Immobilization? Russia is on the Sidelines of Progress}

The problems and trends in the development of rolling stock on the motor transport complex are revealed. The arguments and objections of the transfer of motor vehicles to gas engine fuel and electric traction are given, the strategy of switching to electric vehicles is noted. Data have been obtained showing that electric vehicles are now more economical than cars equipped with internal combustion engines. In the last decade, a rapid electromigration has started in the world, so it would be more correct for Russia to take a course not on transferring transport to gas engine fuel, but for electric traction. Gas would be more effectively used to generate electricity and heat. The progress in the sphere of batteries is to finally and irrevocably send the internal combustion engines to the «dump of history».

Automobile; ecology; gas; motor fuel; gas station; electric vehicle; economic efficiency; price

\section{References}

In Russia in 2017, only 95 new electric vehicles were bought, and 62 of them - Tesla. Available at: https://auto.newsru.com/article/19jan2018/Tesla (accessed 03.06.2018).(In Russ.)

In Japan, the number of charging stations for electric vehicles is already greater than that of traditional ones. Available at: https://avtomaniya.com/site/publicationfull/12500 (accessed 18.06. 2018). (In Russ.)

How Norway refuses gasoline. URL: https://www.the-village.ru/village/city/ abroad/279706-elektrokary-v-norvegii (accessed 18.06.2018). (In Russ.)

The total number of electric vehicles in the world. Available at: https://itc. ua/blogs/obshhee-kolichestvo-elektromobiley-v-mire-prevyisilo-otmetku-2-mlnekzemplyarov-iz-kotoryih-1-2-mln-chistyih-elektromobiley-i-0-8-mln-podklyuchaemyih-gibridov (accessed 25.01.2018).(In Russ.)

Consumption of lithium-ion batteries in Russia. Available at: http://alexmasanov. $\mathrm{ru} / \mathrm{blog} /$ litium-ion-batteryin-russia (accessed 28.02.2018). (In Russ.)

Problems of ecology and pollution of atmospheric air by exhausts of gas of motor transport. Available at: https://vuzlit.ru/1340135/problemy_ekologii_zagryaznenie atmosfernogo_vozduha_vyhlopami_gaza_avtomobilnogo_transporta (accessed 14.06.2018). (In Russ.)

How many electric vehicles are used in the world now: Available at: http:// beelead.com/skolko-elektromobilej-mire (accessed 16.06.2018). (In Russ.)

Faskhiev Kh. A. (2018a). Electric truck with autopilot - the future of longdistance transport. Logistics today. No.1. Pp. 42-56. (In Russ.)

Faskhiev Kh. A. (20186). Economic efficiency of a truck on electric traction. Automobile industry. No.6. Pp. 3-7. (In Russ.)

Four myths about electric cars and the century of gasoline. Available at: https:// republic.ru/biz/1106503 (accessed 28.02.2018). (In Russ.)

Tesla Model S \& Nissan LEAF Clocked As World's Best-Selling Electric Cars In 2016. Available at: https://cleantechnica.com/2017/02/04/tesla-model-s-clockedas-worlds-best- selling-electric-car-in-2016 (accessed 03.06.2018). (In Russ.) 